International Journal of Scholarly Papers for Media and Communications

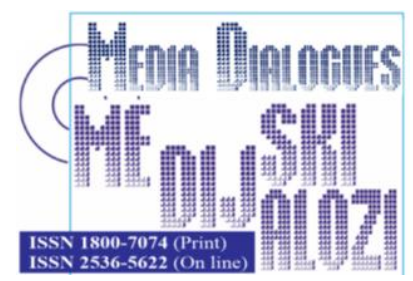

Kostic, N. (2012), „Listen to Your Heart and Do What You Love: a Look at Steve Jobs Through His Own Words", Media Dialogues / Medijski dijalozi,

Vol. 14, No. 2, pp. 51-61.

\title{
Listen to Your Heart and Do What You Love: a Look at Steve Jobs Through His Own Words
}

\author{
Assistant Professor NATAŠA KOSTIC, \\ Institute of Foreign Languages, University of Montenegro, \\ Podgorica, Montenegro
}

\begin{tabular}{|c|c|}
\hline$A R T I C L E$ & Received: October 11, 2020 / Revised from: November 12, 2020 \\
I N F O & Accepted: December 12, 2020 / Available online: January 15, 2021 \\
\hline DOI & doi.org/10.14254/1800-7074/14-1/6 \\
\hline
\end{tabular}

\begin{abstract}
Steve Jobs' natural talent for public speaking was widely noticed and invariably mentioned in descriptions of this truly inspira- tional inventor. This paper gives a brief description of the most re-markable elements of Steve's language, based on his keynote speeches at major trade expos and the Commencement address delivered at Stanford University in 2005. The paper also discusses the great life lessons we can learn from such an amazing person, who had the cou-rage to base his goals on his deepest heart's desires. A strong propo- nent of living life to the fullest, Jobs inspired us to listen to our inner voice and follow it, because he believed it to be the only way to live the life with passion, love, and purpose.
\end{abstract}


KEYWORDS: Steve Jobs, Language, Keynote Speech, Public Speaking, Figures of Speech.

"Have the courage to follow your heart and intuition.

They somehow already know what you truly want to become. Everything else is secondary."

S. Jobs, Commencement address at Stanford University, June 12, 2005

\section{INTRODUCTION}

After the passing of Apple co-founder Steve Jobs on October 5, 2011, there were an estimated 10,000 tweets per second on Twitter social network. Several of the top "trending topics" over the following days were also Jobs-related. The outpouring of sympathy was remarkable, but even more remarkable is the fact that the exact words were inspired by Steve's unique language, making it possible for comments such as "iSad", "ThinkDifferent" or "StayHungry". At the time of his resignation, and again after his death, Jobs was widely described as a visionary, pioneer and genius in the field of business, innovation and product design. After his resignation as Apple's CEO, Jobs was characterized as the Thomas Edison and Henry Ford of his time. As of October 9, 2011, he is listed as either primary inventor or co-inventor in 342 United States patents or patent applications related to a range of technologies from actual computer and portable devices to user interfaces, speakers, keyboards, power adap- ters, staircases, clasps, sleeves, lanyards and packages. He has 43 issued US patents on 27 inventions.

His design was greatly influenced by the Buddhism which he experienced in India while on a seven month spiritual journey at the age of 19. Given his impact on our lives, be it his work in the personal computers (Apple, Macintosh), mobile phones (iPhone), mp3 players (iPod), music distribution (iTunes), tablet computers (iPad) and animation (Pixar), Steve (and his team) has undoubtedly made it much easier for people to work, live, and play, with his creations.

Steve Jobs has been a true role model to many people, in terms of how he lived his life and pursued his dreams. We may know him as the man behind Apple/ iPhone/iPad etc, but there is much more to Steve Jobs than being just the leader of one of the world's most valued companies. 


\section{1. "AND ONE MORE THING"}

Steve Jobs was known for giving presentations that kept his audience enga- ged. He had a natural talent for public speaking that he had honed to an art form and he approached each presentation as an event. Even from the early days of Apple his gift of gab was widely noticed and invariably mentioned in descriptions of Jobs. His power of persuasion was termed "a reality distortion field" by Bud Tribble, an Apple software developer, who described it as "a confounding mélange of a charismatic rhe-torical style, an indomitable will and an eagerness to bend any fact to fit the purpose at hand." This unique talent, according to the ones who had the privilege to work with Jobs, meant that in his presence reality was malleable, that he could convince anyone of practically anything, but it also made it hard to have realistic schedules.

Jobs's power of persuasion was later also applied to his famous keynote speeches (colloquially known as Stevenote addresses or Stevenotes), usually given at major trade expos. In the past, these have included the Macworld Conference \& Expo and the Apple Expo. After 2010, the Worldwide Developer's Conference, organized and held by Apple itself at the Moscone Center in San Francisco, was the only major conference at which Jobs delivered a keynote address. The first thing audience noted in nearly every keynote was his disregard of dress code. His outfit usually consisted of a black long-sleeved St. Croix mock turtleneck, Levi's 501 blue jeans and New Ba- lance 991 sneakers. This dress code expressed various things, most importantly an expression of individuality, anti-traditional, and an egalitarian attitude towards IT workers. Besides the rhetorical techniques, he also used a larger variety of methods and materials in his presentations, since the keynote contains audio-visual elements and technological gadgets. But the most notable moment of each presentation was his magic touch with language. Steve's overall language was colloquial, he never used any difficult or uncommon words, the only exception being words concerned with technology (which was expected since his audience was tech-savvy).

His style of speech included a lot of short sentences, adjectives, superlatives, exclamations, figures of speech and rhetorical questions. However, his sleek words were crucial selling po- ints for Apple's equally sleek products. He had a way of using over-the-top superlati- ves that sounded like they were motivated by pure excitement and a fascination of a 28 customer that bought a great product. He even resembled to a certain degree a child that is fascinated by its new toy, which could be seen by his playfulness and sometimes unconcerned behavior in front of a few thousand people, creating a natural equilibrium for his exaggerations.

In Stevenotes he would introduce new products with such terms as magic, revolutionary, insane-ly great, incredible, breakthrough and unbelievable, or even with sound effects like boom! His gift of showmanship excelled when he would seem to be finishing his presentation, and then say "And one more thing..." before revealing something "insanely great" that he was holding in reserve. 


\section{2. "YOU'VE GOT TO FIND WHAT YOU LOVE"}

Steve wrote and delivered the Commencement speech to the graduates of Stanford University on June 12, 2005, in which he urged graduates to pursue their dreams and fulfill the opportunities in life's setbacks. The style and content are very different from his Apple launch presentations. In one of the most inspiring graduation speeches Steve shared his life lessons via three stories in his life: his birth, when he got fired from Apple, and when he found out about his cancer.

In this speech Jobs adopted a simple and traditional structure, consisting of an opening, three stories and a conclusion. Just like in keynote speeches, he used conversational style and simple sentences, guiding the audience through his own life stories: "Today I want to tell you three stories"..."The first story is about connecting the dots"...My second story is about love and loss"..."My third story is about death".

One of the most important topics in this speech is a recurring theme of birth/ death/rebirth, which underlines it. In a literal sense, Jobs talks about his birth in his first story, and about confronting death in his third story, but the speech contains numerous other metaphorical references to these "circle of life" concepts. For example, his college career had a short "life" and the "death" of his formal academic career made way for the "birth" of his informal learning process; his relationship to Apple in his twenties was "born", grew, and then "died" and when NeXT was purchased by Apple his career at Apple was "reborn"; he received the cancer diagnosis (a "death sentence"), but later was saved by an operation (a rebirth). In the end of the speech Jobs relates these metaphors to his college audience one last time with "as you graduate to begin anew".

Another noteworthy element of this speech includes rich figures of speech, which can also be noted in his presentations. For example, he used antithesis rather effectively, juxtaposing contrasting words in a parallel structure: "If I had never dropped out, I would have never dropped in"..."Again, you can't connect the dots looking forward, you can only connect them looking backwards"..."The heaviness of being successful was replaced by the lightness of being a beginner again"..."Death is very likely the single best invention of Life".

Repetition is often used, adding strength to key arguments, especially in a conclusion. In some examples it takes the form of parallelism ("that my mother had never graduated from college and that my father had never graduated from high school"), in some anadiplosis is used (repetition of a phrase from the end of one sentence at the beginning of the next, e.g. "the only way to be truly satisfied is to do what you believe is great work. And the only way to do great work is to love what you do"), and in some other assonance is employed (repetition of vowel sounds, e.g. "And whenever the answer has been 'No' for too many days in a row, I know I need to change something"). 
The Commencement address at Stanford University is anthological because of the memorable life lessons from such an inspirational figure. Most people probably never assumed that Steve did not have a privileged life and that success was not guaranteed for him. As a matter of fact, he was born out of wedlock, to graduate student parents who gave him up for an adoption; he was adopted and raised in a working class family and his foster father fixed cars for a living; he dropped out of a college, after only one semester, and his highest qualification was high school; in 1985 he was fired, very publicly, from the company he founded (Apple) after losing a power struggle with the board of directors; in 2003 he discovered he had cancerous tumor in his pancreas.

However, rather than let himself paralyzed by the situation and whine about it, he decided to make the best out of what he was given, creating the life he wanted, eventually becoming the CEO of one of the most valued companies in the world, a billionaire, and one of the most respected people in the world. Steve's first life story in Stanford Commencement address is as follows: I am honored to be with you today at your commencement from one of the finest universities in the world. I never graduated from college. Truth be told, this is the closest I've ever gotten to a college graduation. Today I want to tell you three stories from my life. That's it. No big deal. Just three stories.

The first story is about connecting the dots.

I dropped out of Reed College after the first 6 months, but then stayed around as a drop-in for another 18 months or so before I really quit. So why did I drop out? It started before I was born.

My biological mother was a young, unwed college graduate student, and she decided to put me up for adoption. She felt very strongly that I should be adopted by college graduates, so everything was all set for me to be adopted at birth by a lawyer and his wife. Except that when I popped out they decided at the last minute that they really wanted a girl. So my parents, who were on a waiting list, got a call in the middle of the night asking: "We have an unexpected baby boy; do you want him?" They said: "Of course." My biological mother later found out that my mother had never graduated from college and that my father had never graduated from high school. She refused to sign the final adoption papers. She only relented a few months later when my parents promised that I would someday go to college.

And 17 years later I did go to college. But I naively chose a college that was almost as expensive as Stanford, and all of my working-class parents' savings were being spent on my college tuition. After six months, I couldn't see the value in it. I had no idea what I wanted to 30 do with my life and no idea how college was going to help me figure it out. And here I was spending all of the money my parents had saved their entire life. So I decided to drop out and trust that it would all work out OK. It was pretty scary at the time, but looking back it was one of the best decisions 
I ever made. The minute I dropped out I could stop taking the required classes that didn't interest me, and begin dropping in on the ones that looked interesting.

It wasn't all romantic. I didn't have a dorm room, so I slept on the floor in friends' rooms, I returned coke bottles for the $5 \phi$ deposits to buy food with, and I would walk the 7 miles across town every Sunday night to get one good meal a week at the Hare Krishna temple. I loved it. And much of what I stumbled into by following my curiosity and intuition turned out to be priceless later on. Let me give you one example:

Reed College at that time offered perhaps the best calligraphy instruction in the country. Throughout the campus every poster, every label on every drawer, was beautifully hand calligraphed. Because I had dropped out and didn't have to take the normal classes, I decided to take a calligraphy class to learn how to do this. I learned about serif and san serif typefaces, about varying the amount of space between different letter combinations, about what makes great typography great. It was beautiful, historical, artistically subtle in a way that science can't capture, and I found it fascinating.

None of this had even a hope of any practical application in my life. But ten years later, when we were designing the first Macintosh computer, it all came back to me. And we de-signed it all into the Mac. It was the first computer with beautiful typography. If I had never dropped in on that single course in college, the Mac would have never had multiple typefaces or proportionally spaced fonts. And since Windows just copied the Mac, it's likely that no per-sonal computer would have them. If I had never dropped out, I would have never dropped in on this calligraphy class, and personal computers might not have the wonderful typography that they do. Of course it was impossible to connect the dots looking forward when I was in college. But it was very, very clear looking backwards ten years later.

Again, you can't connect the dots looking forward; you can only connect them looking backwards. So you have to trust that the dots will somehow connect in your future. You have to trust in something - your gut, destiny, life, karma, whatever. This approach has never let me down, and it has made all the difference in my life.

With his simple words and illustrative examples Steve showed us that even when things looked bleak, he managed to find the faith that they would work out the best possible way one day. No matter what rough patch he went through at the moment, he did not give up, but kept going and tried to make the best out of his life. $\mathrm{He}$ urged us not to lose hope, but to trust in the truth that everything happens for a reason.

Before Apple's rise in the last decade, Microsoft was the undisputed giant in the world of personal computers. Before iPod, mp3 players were known only as mp3 players and before iTunes it seemed almost unlikely for anyone to pay for music onli- ne, when music piracy was so widespread. And before iPhone, Nokia was the 
longtime market leader for mobile phones. Even before iPad there didn't seem to be a need for tablet computers. In other words, in each situation no one would ever thought things would change. However, the status quo was broken each time, and with exceeding results. With each of these new products, Steve (and its team) revolutionized the industry and created a new movement. These happened because Steve had the coura- ge to think outside the box and to base his goals on his deepest heart's desires. This is how he taught Stanford students to do the same in his second life story:

My second story is about love and loss.

I was lucky - I found what I loved to do early in life. Woz and I started Apple in my parents garage when I was 20. We worked hard, and in 10 years Apple had grown from just the two of us in a garage into a $\$ 2$ billion company with over 4000 employees. We had just released our finest creation - the Macintosh - a year earlier, and I had just turned 30. And then I got fired. How can you get fired from a company you started? Well, as Apple grew we hired someone who I thought was very talented to run the company with me, and for the first year or so things went well. But then our visions of the future began to diverge and eventually we had a falling out. When we did, our Board of Directors sided with him. So at I was out. And very publicly out. What had been the focus of my entire adult life was gone, and it was devastating.

I really didn't know what to do for a few months. I felt that I had let the previous generation of entrepreneurs down - that I had dropped the baton as it was being passed to me. I met with David Packard and Bob Noyce and tried to apologize for screwing up so badly. I was a very public failure, and I even thought about running away from the valley. But something slowly began to dawn on me - I still loved what I did. The turn of events at Apple had not changed that one bit. I had been rejected, but I was still in love. And so I decided to start over.

I didn't see it then, but it turned out that getting fired from Apple was the best thing that could have ever happened to me. The heaviness of being successful was replaced by the lightness of being a beginner again, less sure about everything. It freed me to enter one of the most creative periods of my life.

During the next five years, I started a company named NeXT, another company named Pixar, and fell in love with an amazing woman who would become my wife. Pixar went on to create the worlds first computer animated feature film, Toy Story, and is now the most successful animation studio in the world. In a remarkable turn of events, Apple bought NeXT, I returned to Apple, and the technology we developed at NeXT is at the heart of Apple's current renaissance. And Laurene and I have a wonderful family together.

I'm pretty sure none of this would have happened if I hadn't been fired from Apple. It was awful tasting medicine, but I guess the patient needed it. Sometimes life hits you in the head with a brick. Don't lose faith. I'm convinced that the only 
thing that kept me going was that I loved what I did. You've got to find what you love. And that is as true for your work as it is for your lovers. Your work is going to fill a large part of your life, and the only way to be truly satisfied is to do what you believe is great work. And the only way to do great work is to love what you do. If you haven't found it yet, keep looking. Don't settle. As with all matters of the heart, you'll know when you find it. And, like any great relationship, it just gets better and better as the years roll on. So keep looking until you find it. Don't settle.

Steve Jobs started Apple in his parent's garage along with his school friend, which was not the most glamorous start for the world's largest technology company today. However, if he had been waiting forever for things to be perfect, he would never have achieved anything. He was fired from the very company he created, which would, by most people's standards, be the epitome of failure. However, he went on to create two successful companies (NeXT and Pixar), got rehired into Apple, turned it around in one of the biggest comebacks in business history, and made it the biggest technology company today. The message this amazing man sent us is that he never gave up on himself and fought for what he believed in. The setbacks we experience in our life are only one of the many mid-points towards our end goal. As long as we keep going and have no intentions to give up on our dreams, it is just a matter of time before we get where we want to be. As Apple's co-founder Steve Wozniak said about Jobs: "People sometimes have goals in life. Steve Jobs exceeded every goal he ever set for himself."

Jobs also talked about the importance of pursuing one's passion all the time. His example showed us that as long as one delivers top value and keeps outdoing oneself, it is a matter of time before one achieves both passion and success. He is the one who demonstrated that life is about doing the very things one loves. The question he made us and his audience ask themselves is: Am I living my life to the fullest? In his third story in the Stanford address he gave his answer:

My third story is about death.

When I was 17, I read a quote that went something like: "If you live each day as if it was your last, someday you'll most certainly be right." It made an impression on me, and since then, for the past 33 years, I have looked in the mirror every morning and asked myself: "If today were the last day of my life, would I want to do what I am about to do today?" And whenever the answer has been "No" for too many days in a row, I know I need to change something. Remembering that I'll be dead soon is the most important tool I've ever encountered to help me make the big choices in life. Because almost everything - all extenal expectations, all pride, all fear of embarrassment or failure - these things just fall away in the face of death, leaving only what is truly important.

Remembering that you are going to die is the best way I know to avoid the trap of thinking you have something to lose. You are already naked. There is no reason not to follow your heart. 
About a year ago I was diagnosed with cancer. I had a scan at 7:30 in the morning, and it clearly showed a tumor on my pancreas. I didn't even know what a pancreas was. The doctors told me this was almost certainly a type of cancer that is incurable, and that I should expect to live no longer than three to six months. My doctor advised me to go home and get my affairs in order, which is doctor's code for prepare to die. It means to try to tell your kids e-verything you thought you'd have the next 10 years to tell them in just a few months. It means to make sure everything is buttoned up so that it will be as easy as possible for your family. It means to say your goodbyes.

I lived with that diagnosis all day. Later that evening I had a biopsy, where they stuck an endoscope down my throat, through my stomach and into my intestines, put a needle into my pancreas and got a few cells from the tumor. I was sedated, but my wife, who was there, told me that when they viewed the cells under a microscope the doctors started crying because it turned out to be a very rare form of pancreatic cancer that is curable with surgery. I had the surgery and I'm fine now.

This was the closest I've been to facing death, and I hope it's the closest I get for a few more decades. Having lived through it, I can now say this to you with a bit more certainty than when death was a useful but purely intellectual concept:

No one wants to die. Even people who want to go to heaven don't want to die to get there. And yet death is the destination we all share. No one has ever escaped it. And that is as it should be, because Death is very likely the single best invention of Life. It is Life's change agent. It clears out the old to make way for the new. Right now the new is you, but someday not too long from now, you will gradually become the old and be cleared away. Sorry to be so dramatic, but it is quite true.

Your time is limited, so don't waste it living someone else's life. Don't be trapped by dogma - which is living with the results of other people's thinking. Don't let the noise of others' opinions drown out your own inner voice. And most important, have the courage to follow your heart and intuition. They somehow already know what you truly want to become. Everything else is secondary.

When I was young, there was an amazing publication called The Whole Earth Catalog, which was one of the bibles of my generation. It was created by a fellow named Stewart Brand not far from here in Menlo Park, and he brought it to life with his poetic touch. This was in the late 1960's, before personal computers and desktop publishing, so it was all made with typewriters, scissors, and polaroid cameras. It was sort of like Google in paperback form, 35 years before Google came along: it was idealistic, and overflowing with neat tools and great notions.

Stewart and his team put out several issues of The Whole Earth Catalog, and then when it had run its course, they put out a final issue. It was the mid-1970s, and I was your age. On the back cover of their final issue was a photograph of an early morning country road, the kind you might find yourself hitchhiking on if you were so 
adventurous. Beneath it were the words: "Stay Hungry. Stay Foolish." It was their farewell message as they signed off. Stay Hungry. Stay Foolish. And I have always wished that for myself. And now, as you graduate to begin anew, I wish that for you.

Stay Hungry. Stay Foolish.

Thank you all very much.

Jobs was a strong proponent of living life to the fullest, every day. If he had listened to his detractors when he was fired, he would never have achieved the success he did. Rather, he listened to his heart and did what he felt he had to do. Being guided by that led him to realize his goals and make meaning out of his life. Jobs inspired us to listen to our inner voice and follow it, because we can never go wrong with it. He reminds us not to live our life in regret, because life is meant to be lived with passion, with love, conviction and purpose. What we all cannot help loving about Steve Jobs is how he pursued betterment, both in his life and his work. He was already successful in his early years, but this did not stop him from wanting to become even better. He kept pushing for innovation, each time creating one game changing product after another. Because of that, he kept growing, and so did Apple. He was an inspirational man with an incredible spirit.

\section{CONCLUSION}

Since Job's death, millions of people have watched the YouTube video of his most inspirational Commencement address at Stanford University in 2005. The farewell message that Jobs quoted ("Stay Hungry. Stay Foolish") is a fitting farewell for Jobs, too, as he always hungered for new ideas and new words to express them, without fear of being called foolish in the process. Jobs was a perfectionist who always aspired to foresee and set trends, especially in innovation and style. He summed up that self-concept at the end of his keynote speech at the Macworld Conference and Expo in January 2007, by quoting ice hockey player Wayne Gretzky: "There's an old Wayne Gretzky quote that I love. 'I skate to where the puck is going to be, not where it has be- en.' And we've always tried to do that at Apple. Since the very beginning. And we always will."

\section{REFERENCES}

Campbell, D. (2004), "The Guardian Profile: Steve Jobs”, The Guardian (UK), June 8, 2004.

Jobs, S. (2005), "You've got to find want you love", a prepared text of the Commencement address delivered by Steve Jobs, CEO of Apple Computer and of Pixar Animation Studios, on June 12, 2005. Stanford Report, June 14, 2005.

McCracken, H. (2011), "Steve Jobs, 1955-2011: Mourning Technology's Great Reinventor", Time, October 5, 2011. 
Simon, W. L, Young, J. S. (2005), iCon: Steve Jobs, The Greatest Second Act in the History of Business, John Wiley and Sons, New Jersey.

Stross, R. E. (1993), Steve Jobs and The NeXT Big Thing, Atheneum Books.

http://itmanagersinbox.com/1643/learn-to-give-better-presentations-from-stevejobs/ Wikipedia, the free encyclopedia,

http://en.wikipedia.org/wiki/Steve_Jobs 